\title{
Human Dignity and Human Rights as a Common Ground for a Global Bioethics
}

\author{
ROBERTO ANDORNO \\ University of Zurich, Zurich, Switzerland
}

\begin{abstract}
The principle of respect for human dignity plays a crucial role in the emerging global norms relating to bioethics, in particular in the UNESCO Universal Declaration on Bioethics and Human Rights. This instrument, which is a legal, not merely an ethical document, can be regarded as an extension of international human rights law into the field of biomedicine. Although the Declaration does not explicitly define human dignity, it would be a mistake to see the emphasis put on this notion as a mere rhetorical strategy. Rather, the appeal to dignity reflects a real concern about the need to promote respect both for the intrinsic worth of human beings and for the integrity of the human species. But dignity alone cannot solve most of the dilemmas posed by biomedical practice. This is why international biolaw combines, on the one hand, the appeal to buman dignity as an overarching principle with, on the other hand, the recourse to buman rights, which provide an effective and practical way forward for dealing with bioethical issues at a global level.
\end{abstract}

Keywords: global bioethics, human dignity, human rights, international law, UNESCO

\section{INTRODUCTION}

Recent intergovernmental instruments specifically dealing with biomedicine, particularly those adopted since the end of the 1990s by the United Nations Educational, Scientific, and Cultural Organization (UNESCO) and the Council of Europe, assign a very central role to the notion of human dignity, which is presented as the ultimate rationale behind the new rules relating to this matter.

Address correspondence to: Roberto Andorno, Institute of Biomedical Ethics, School of Medicine, University of Zurich, Zollikerstrasse 115, 8008 Zurich, Switzerland. E-mail: andorno@ethik.uzh.ch

(c) The Author 2009. Published by Oxford University Press, on behalf of the Journal of Medicine and Philosophy Inc. All rights reserved. For permissions, please e-mail: journals.permissions@oxfordjournals.org 
At the same time, they appeal to a human rights framework as a way to reinforce their provisions and to articulate specific rules to govern this field. The aim of this paper is to examine the recourse to human dignity and human rights in the field of global bioethics, with particular reference to the 2005 UNESCO Universal Declaration on Bioethics and Human Rights. To this end, after some preliminary remarks about the relationship between bioethics and law, this paper will first briefly examine the meaning and value of the notion of human dignity in the international norms relating to bioethics; second, it will argue that human dignity and human rights are the best, if not the only available grounds for the development of international legal standards for biomedicine.

\section{BIOETHICS AND LAW: WHAT RELATIONSHIP?}

The Term "Bioethics" May Also Be Understood As Including the Legal Aspects of Biomedical Issues

Before focusing on the role played by human dignity and human rights in global bioethics, two preliminary remarks ought to be made. The first relates to the meaning of the word "bioethics," which is terribly ambiguous and may lead to serious misunderstandings. Depending on the context, it can be used with a narrow meaning or with a broad meaning. The narrow meaning refers to the purely ethical dimension of life sciences. From this perspective, bioethics is just a part of ethics. When the term "bioethics" is so understood, it is a contradiction in terms to speak of "laws on bioethics" because what is ethical or unethical is not, and indeed cannot, be prescribed by law. Though ethics and law interact in various ways and may significantly overlap with one another, they remain as two different normative systems, for the simple reason that they pursue different goals: ethics reflects the effort of our reason in discovering whether something is right or wrong and aims at promoting the fulfillment of our tendencies toward the good, at least according to the classical, or Aristotelian, view on ethics. In contrast, law has a much narrower scope than ethics, because it does not seek to make men moral, even if legal norms certainly have an indirect positive impact on the moral fulfillment of persons. The basic purpose of law is just to ensure that human relationships are governed by the principle of justice, or in other words, that the rights of each individual, as well as the common interests of society as a whole, are guaranteed. Whereas the fundamental question of ethics is "What should I do to become a better person?," the key question of law is "What rules do we need to promote a peaceful and fair society?"

In an attempt to illustrate the intricate relationship between ethics and law, the German legal philosopher Jellinek (1908, 45) characterized law as "the minimum ethics" (das ethische Minimum). By this expression, he meant that law only embodies those moral requirements that have to do with "the indispensable conditions of social life." An understanding of the different objectives 
that ethics and law try to achieve is key to grasp why ethics inevitably covers and will always cover a much broader spectrum than law; it also shows why what is unethical is not (and should not be) necessarily illegal. Only a totalitarian regime could attempt, with any chance of success, to make them overlapping. The distinction between these realms is extremely important, and in a field like bioethics, in which one may have the impression that they fuse, it should be carefully maintained. In this regard, it is noteworthy that, precisely in order to prevent any confusion between ethics and law, the Council of Europe has preferred to avoid the use of the word "bioethics" in the Convention on Human Rights and Biomedicine adopted in 1997. This is the reason why even the title of this instrument, which included the term "bioethics" in its draft version, was changed from "Convention on Human Rights and Bioethics" to "Convention on Human Rights and Biomedicine."

But this risk of confusion can be eliminated by explaining that the term "bioethics" can also be used with a broad meaning, which in addition to biomedical ethics, also includes the legal aspects of biomedical issues (sometimes called "biomedical law" or simply "biolaw"). In this respect, "regulatory and policy bioethics" has been sometimes mentioned as one of the four main varieties of "bioethics" (Callahan, 2004, 281). The possibility of such a broad understanding of the term "bioethics," which may include rules and issues of a legal nature, explains why this word can be used without any embarrassment by the UNESCO declarations, which far from attempting to "subsume medical ethics" (Faunce, 2005, 177), are indeed conceived as an extension of international human rights law into the field of biomedicine.

\section{Soft Law Is Law, Not Ethics}

The second preliminary remark is closely connected with the first one and relates to the status of the UNESCO declarations. There is a widely diffused idea that these documents are purely ethical or rhetorical recommendations deprived of any legal effect. This view probably stems from the fact that, unlike treaties, the UNESCO declarations, as any "soft law" agreements, are usually characterized as "nonbinding instruments." Although this depiction is not entirely wrong, it may be misleading because while soft law does not have a binding effect per se, it is conceived to have such effect in the long term. This means that although treaties are actually binding (after ratification by states), soft law instruments are only potentially binding. Soft law is indeed envisaged as the beginning of a gradual process in which further steps are needed to make of such agreements binding rules for states.

It is noteworthy that the use of soft law has rapidly developed in recent decades as a new source of international law for dealing with particularly sensitive matters such as human rights, the protection of the environment, and bioethical issues. Soft law presents the great advantage of allowing countries to gradually become familiar with the commonly agreed standards 
before they are confronted with the adoption of enforceable rules at the national or international level. This gradual procedure leaves more room for discussion and achieving consensus on issues that are especially complex or sensitive, or more exposed to change, like those related to scientific developments (Lenoir and Mathieu, 1998, 45).

The most notable example of the significant role that soft law can play in the development of binding norms is provided by the Universal Declaration of Human Rights (UDHR) of 1948. This document, which took the form of a soft law instrument, is today widely recognized as the cornerstone of the entire international human rights system that emerged in the aftermath of the Second World War. The UDHR did not only pave the way for the adoption of more than seventy treaties, which are applied today on a permanent basis at global and regional levels, but also served as a model for many constitutions and laws throughout the world and helped to ground uncountable decisions of national and international courts (Cançado Trinidade, 2008, 2).

Regarding the UNESCO declarations, it is important to note that if the binding effect were totally absent from them, they would not be "law" at all because one of the classical distinctions between "ethics" and "law" is precisely that law is made up of enforceable norms whereas ethics is not enforceable. Thus, it is somehow misleading to affirm that soft law only creates moral or political commitment for states. This is only true if we consider the immediate effect of soft law instruments. But the fact is that, in a more indirect and persuasive way, they have an influence on states which is not very different from that of treaties. Indeed, some studies show that, surprisingly, declarations and treaties are complied with to largely the same extent (Hillgenberg, 1999, 502). We should not forget that, after all, soft law instruments are formal intergovernmental agreements, and in this respect, they do not differ essentially from the traditional international binding instruments.

Furthermore, there is no doubt that the UNESCO declarations have been adopted with the intention that in the long run, in one way or another, they will become binding rules for states. This "hardening" of soft law may happen in two different ways. One is when declarations are the first step toward a treaty-making process, in which reference will be made to the principles already stated in the declarations. Another possibility is that nontreaty agreements are intended to have a direct influence on the practice of states, and to the extent that they are successful in doing so, they may lead to the creation of customary law. As some experts explain, declarations may "catalyse the creation of customary law by expressing in normative terms certain principles whose general acceptance is already in the air ... and thereby making it easier and more likely for states to conform their conduct to them" (Szasz, 1992, 60). Thus, if the same nonbinding standards are reaffirmed in successive international treaties, or invoked by international courts to support their decisions, in the course of time they may become binding rules in the form of customary law, as it happened with the UDHR of 1948 (Dimitrijevic, 2006, 8-10). 


\section{HUMAN DIGNITY: THE OVERARCHING PRINCIPLE OF GLOBAL BIOETHICS}

The principle of respect for human dignity holds a prominent position in the intergovernmental instruments dealing with bioethics that have been adopted during the last decade. The emphasis on human dignity is impressive enough to lead scholars to characterize this notion as "the shaping principle" of international bioethics (Lenoir and Mathieu, 1998, 16). Far from representing a shift merely in style, the higher profile accorded to this notion in bioethics is seen as a true shift in substance that needs to be carefully considered (Beyleveld and Brownsword, 2002, 29). Thus, it is not surprising that the 2005 Universal Declaration on Bioethics and Human Rights, which formulates a set of norms to guide biomedical practice, assigns the first place to the principle of respect for "human dignity, human rights and fundamental freedoms" (Article 3.1).

Certainly, the recourse to human dignity is neither new in international law nor specific to policy documents relating to bioethics. The abovementioned UDHR of 1948 states in its Preamble that "the inherent dignity" of all members of the human family is "the foundation of freedom, justice and peace in the world." Thereafter, the idea of human dignity has been at the heart of the major human rights instruments, beginning with the two international covenants on human rights adopted in 1966: the International Covenant on Civil and Political Rights (ICCPR) and the International Covenant on Economic, Social, and Cultural Rights (ICESCR), as well as in most treaties banning torture, slavery, inhuman and degrading treatments, and discriminations of all sorts.

Nevertheless, although the notion of human dignity has always held an important position in international law, the key role it plays in the emerging international biomedical law is really impressive. It is therefore not exaggerated to characterize it as the "overarching principle" of international biolaw. Regarding the 2005 UNESCO Declaration, respect for human dignity not only is placed first in the list of principles that should govern the biomedical field (Article 3) but also embodies the central aim of the whole instrument (Article 2.c). Furthermore, it is interesting to note that the need to include the principle of respect for human dignity was one of the points most often mentioned by member states during the worldwide consultations that took place between January and March 2004 (UNESCO, 2004, 2).

What are the reasons for this emphasis on human dignity in global bioethics? The first obvious reason is that biomedical practice is closely related to the most basic human rights, namely the rights to life, to physical integrity, to privacy, to access to basic health care, among others. If human dignity is generally recognized as the foundation on which human rights are based, then it is not surprising that it is invoked as the ultimate rationale of the legal norms governing biomedical practice. But there is another reason explaining 
this phenomenon. The notion of human dignity is beginning to be seen as the last barrier against the alteration of some basic features of the human species that might result from practices such as reproductive cloning or germ-line interventions. It should be noted that resorting to human rights is insufficient to cope with these new challenges because human rights only belong to existing individuals, not to humanity as such. In fact, an act like reproductive cloning, which is done prior to the existence of an individual cannot, by definition, infringe the rights and dignity of that individual. This is so because the so-called "future persons," who are contingent in the sense that they may or not come into existence, are not persons at all, neither from a legal nor from a philosophical perspective. Thus, reproductive cloning, as well as germ-line interventions may be seen as a threat, not to individuals, but to the integrity of the human species as such (Annas, Andrews, and Isasi, 2002, 151-78). This is the reason why the 1997 Universal Declaration on the Human Genome and Human Rights directly appeals to the notion of human dignity, not to human rights, to reject both practices (Articles 11 and 24).

Even though the notion of dignity is not defined by the UNESCO instruments, the 2005 Declaration provides a significant contribution to the understanding of this concept. Article 3.2 stipulates that "the interests and welfare of the individual should have priority over the sole interest of science or society." This basic principle had been outlined for the first time in 1964 in the famous Declaration of Helsinki for medical research on human subjects developed by the World Medical Association. Thereafter, it was incorporated into the 1997 Universal Declaration on the Human Genome and Human Rights (Article 10) and into the 1997 European Convention of Human Rights and Biomedicine (Article 2). The primacy of the human being over science is indeed a direct corollary of the principle of respect for human dignity and aims to emphasize two fundamental ideas. First, that science is not an end in itself but only a means for improving the welfare of individuals and society. Second, that people should not be reduced to mere instruments for the benefit of science. Certainly, the fact of living in society renders it indispensable that citizens should in some way contribute to the common good, according to their capacities and preferences. However, in democratic societies, people do not live for the sake of society or science, but have their own purpose, which greatly transcends the boundaries of social or scientific interests. This is precisely the key message that Article 3.2 of the UNESCO Declaration wants to deliver.

\section{CAN 'HUMAN DIGNITY' BE DEFINED BY LAW?}

Although the notion of human dignity is at the heart of the major international human rights instruments, it is never explicitly defined by them. They provide however a valuable guidance for the understanding of this concept 
when they state: first, that dignity is "inherent ... to all members of the human family" (UDHR, Preamble); second, that all human beings are "free and equal in dignity and rights" (UDHR, Article 1); and third, that "these rights derive from the inherent dignity of the human person" (ICCPR and ICESCR, Preambles).

These three ideas, even though they may appear to be extremely vague, offer a precious guidance for clarifying the meaning with which the notion of human dignity is used by international law:

a. The term "inherent" means "involved in the constitution or essential character of something," "intrinsic," "permanent or characteristic attribute of something." The idea expressed in this term, when it is accompanied by the adjective "human," is that dignity is inseparable from the buman condition. Thus, dignity is not an accidental quality of some human beings, or a value derived from some specific personal features such as the fact of being young or old, man or woman, healthy or sick, but rather an unconditional worth that everyone has simply by virtue of being human. The same idea can be expressed by saying that all human beings are "persons." Indeed, the term "person" is not merely descriptive or generic (like for instance "mammal"), but prescriptive, a nomen dignitatis (Spaemann, 1996, 13).

b. The second important consequence of the meaning that "human dignity" bears in international law is that basic rights are equal for all: if human dignity is the same for all and the ground of human rights, then all human beings possess equal basic rights. This is the reason why discrimination, i.e. the unjust distinction in the treatment of different categories of people, is directly contrary to human dignity.

c. The third statement of international law stressing that rights derive from human dignity, has also an important practical consequence: if basic rights are not given by authority, but are pre-existing values which are inherent in every human being, then they cannot be legitimately taken away (Schachter, 1983, 853).

Considering these three basic features of human dignity, it is not surprising that this notion is at the center of human rights instruments prohibiting practices such as torture, inhuman or degrading treatments, slavery, exploitative working conditions, discrimination, arbitrary arrests, etc. But even in these cases, the term is not explicitly defined by international law. Rather, its meaning is "left to intuitive understanding, conditioned in large measure by cultural factors" (Schachter, 1983, 849). The UNESCO Universal Declaration on Bioethics and Human Rights is not an exception in this regard, as it does not attempt to provide any definition of this concept.

It would be however a mistake to conclude from this lack of definition that dignity is a simple slogan that means no more than "respect for autonomy" and therefore could simply be eliminated without any loss of content (Macklin, 2003, 1419).

Certainly, the concept of human dignity is open to abuse and misinterpretation. But the same happens with all basic moral and legal principles (justice, freedom, autonomy, etc.), which are normally not defined by law, 
not only because of the impossibility of finding a precise definition of such fundamental concepts that satisfies everyone, especially in a transcultural context, but also because lawmakers are well aware that rigid definitions may in some cases lead to unsolvable difficulties in the implementation of legal norms. In this regard, they prefer to follow the old Roman dictum: omnis definitio in iure periculosa est ("every definition in law is perilous").

It is also true that bioethical debates often show an inflationary use of the term "dignity" that should be avoided, especially when no additional explanation is given to make it clear why a particular practice is regarded as being in conformity (or not) with this basic principle. In such cases, dignity appears to be used as "mere rhetorical dressing, adding little more to the policy debate than the weight or cachet of the concept" (Caulfield and Chapman, 2005, 737).

However, beyond all the abusive rhetoric that may surround this notion, a careful analysis of intergovernmental policy documents relating to bioethics, and of the discussion that led to their adoption, puts in evidence that the recourse to human dignity reflects a real concern about the need to ensure respect for the inherent worth of every human being. This concern is far broader than simply ensuring "respect for autonomy" for the simple reason that it also includes the protection of those who are not yet, or are no more, morally autonomous (newborn infants, senile elderly, people with serious mental disorders, comatose patients, etc.). As noted above, this broad view of the concept of human dignity is clearly enshrined in international human rights law, which assumes that the worth of human beings does not rest on their actual intellectual or moral abilities, but merely on their buman condition.

\section{IS DIGNITY A SYNONYM FOR "RESPECT"?}

There is no doubt that the concept of "dignity" is very close to that of "respect." However, it would be a mistake to identify both concepts or to think that we can avoid the difficulties posed by the abstract notion of dignity just by replacing it with the more practical idea of respect. This would be a false solution because respect for persons is just the consequence of human dignity, not dignity itself, in a similar way that the bell's sound is an effect produced by the bell, not the bell itself. Moreover, this explanation would inevitably beg the question and lead to circular reasoning: "we are obliged to respect persons because ... they deserve respect." In fact, the idea of dignity is not a synonym for respect for the simple reason that dignity is what provides the rationale to the requirement of respect for persons.

In modern times, Kant was probably the first major philosopher to put the notions of respect (Achtung) and dignity (Würde) at the very center of moral theory. Even though one may disagree with his excessively formalistic view of ethics, one has to acknowledge that his famous second formulation of the categorical imperative is very helpful for understanding the practical consequences 
of the notion of dignity. According to this principle, we should always treat people as an end in themselves (Zweck an sich selbst) and never merely as a means to our ends. The reason is that human beings are not "things," but "persons" and hence not something that can be used merely as a means. Although things have a price, that is, the kind of value for which there can be equivalent, dignity makes a person irreplaceable (Kant, 1996, 79).

The Kantian requirement of noninstrumentalization (or noncommodification) of persons is extremely illuminating in bioethics. It means, for instance, that no one should be subjected to biomedical research without his or her informed consent, even when very valuable knowledge could result from that research; it also means that law must prevent poor people from being induced to sell their organs as a means to support themselves or their families (Cohen, 2002, 59). These two examples illustrate that the idea of dignity as a requirement of noninstrumentalization of persons, far from being purely rhetorical, has some immediate applications. But beyond such extreme examples, the view that people have inherent worth plays a major role in everyday medical practice and can greatly contribute to enhance the quality of the doctor-patient relationship. More concretely, this vision helps to keep alive in the minds of health care professionals the conviction that each patient, no matter what his or her diagnosis, is not a "case," a "disease," or a "room number," but a person that deserves to be treated with the greatest respect and care.

\section{THE VARIOUS FUNCTIONS OF HUMAN DIGNITY IN BIOETHICS}

To understand how the notion of human dignity operates in bioethics, it is essential to make some conceptual distinctions, particularly between the above-described inberent dignity of the human person and the moral dignity, which is a synonym of "honor." Whereas the former plays a central role in legal instruments relating to bioethics, the latter has much less relevance in this field. Thus, it must be assumed that this notion is used in the first sense, unless it is clearly indicated otherwise.

On the one hand, the inherent dignity, as it is inseparable from the human condition, is the same for all, cannot be gained or lost and does not allow for any degree (Spiegelberg, 1970, 55). Even the worst criminal cannot be stripped of his or her human dignity and should consequently not be subjected to inhuman treatments or punishments. Dworkin (1994, 236) employs the expression human dignity with this meaning when he points out that it refers to "the intrinsic importance of human life" and requires that "people never be treated in a way that denies the distinct importance of their own lives."

On the other hand, moral dignity does not relate to the existence itself of persons, but to their behavior and stems from their ability to freely choose good and to contribute beneficially to their own lives and the lives of others. 
It can be said that we give to ourselves this second kind of dignity by making good moral choices. This is why, unlike inherent dignity, which is the same for all, moral dignity is not possessed by all individuals to the same degree. Indeed, we can say, for instance, that an honest man has "more dignity" than a thief.

Alan Gewirth makes this same distinction when he writes that:

[t]he sense of 'dignity' in which all humans are said to have equal dignity is not the same as that in which it may be said of some person that he lacks dignity or that he behaves without dignity ... This kind of dignity is one that humans may occasionally exhibit, lack, or lose, whereas the dignity in which all humans are said to be equal is a characteristic that belongs permanently and inherently to every human as such (1982, 27-8).

Another distinction that has been suggested as being relevant to bioethics is between "human dignity as empowerment" and "human dignity as constraint" (Beyleveld and Brownsword, 2002, 1-47). Whereas the former emphasizes freedom to pursue one's autonomously chosen goals, the latter is more concerned with duties than with human rights and acts as a constraint on freedom in the interest of the common good. Beyleveld and Brownsword characterize both notions as "opposed" or "competing" and argue that although the founding international instruments of human rights appeal to the first conception of human dignity, dignity as constraint would be typical of the recent instruments dealing with biomedicine and much more controversial.

Nevertheless, this distinction, at least as it is presented, is somehow misleading. These two facets of human dignity do not really constitute rival notions. They are not mutually exclusive but complementary, in the same way that "rights" and "duties" or "freedom" and "responsibility" are complementary concepts. Indeed, the same principle stating that human beings have intrinsic worth results in two consequences. First, that each individual is entitled to fundamental rights and freedoms. Second, that people deserve to be protected from serious threats to their dignity, even if they might appear to be consenting to such acts. The reason for the complementary nature of these two facets of human dignity is that most rights are not absolute but subject to such reasonable limits as are generally accepted in a free and democratic society, as it is explicitly recognized by all major international human rights instruments. In this regard, for instance, Article 12.3 of the ICCPR stipulates that:

[t]he above-mentioned rights shall not be subject to any restrictions except those which are provided by law, are necessary to protect national security, public order (ordre public), public health or morals or the rights and freedoms of others, and are consistent with the other rights recognized in the present Covenant.

As a matter of fact, the notion that individual freedoms can be restricted to ensure respect for human dignity is neither new nor specific to the instruments dealing with biomedicine. Rather on the contrary, such restrictions are 
quite common in legal documents, both at the domestic and international level. Just to give two examples: labor laws do not allow workers to waive their basic rights and benefits or to accept working conditions close to slavery; contract laws do not recognize the validity of contracts containing terms that are unfairly burdensome to one party and unfairly beneficial to the other. Thus, from this perspective, there is nothing new in the recent instruments relating to biomedicine, except that they cover novel issues. This is why, rather than presenting "dignity as constraint" as a new concept and opposed to "dignity as empowerment," it would be perhaps more accurate to describe both perspectives as being two facets of the same need to ensure respect for people. In this line of thinking, some scholars suggest distinguishing between the "subjective" and the "objective" dimensions of dignity, which are complementary and correspond to freedom and to restrictions of freedom respectively (Manaï, 2006, 20-4).

Another distinction that needs to be made is between the "individual" and the "collective" dimensions of dignity. The former is the primary expression of dignity and the ground of all basic rights and freedoms, whereas the latter is another, more recently developed category of dignity that goes far beyond the mere individual sphere and refers to the value of humanity as such, including future generations. This distinction has been suggested by Birnbacher (1996, 114-15) among others. Whereas individual dignity refers to the idea that every human being has inherent worth, collective dignity is a derivative notion, which embodies the idea that the existence and integrity of humanity as such also has intrinsic worth and therefore also deserves to be protected. This extended notion of dignity lies in the background of some international instruments dealing with biotechnological developments that may affect basic features of the human species, like reproductive cloning and germ-line interventions. It amounts to a sort of "species solidarity" (Manaï, 2006, 20-2) and inevitably leads to prescribe some limits on potential developments that could be harmful for the identity and integrity of humanity.

It is important to stress, however, that collective dignity is only a derivative notion because dignity belongs primarily to the individual. As Teresa Iglesias points out while commenting on the UDHR:

Upholding 'human dignity' or the 'dignity of the species' without upholding the dignity of each one and of all, is not to uphold dignity in its universal significance. In the name of the 'dignity of the whole' (of a 'whole' group) others have come to suffer the atrocities to which the Declaration refers $(2001,13)$.

It is also noteworthy here that an analysis of international human rights instruments and of the decisions of national and international courts shows indeed that human dignity does not play just one, but several roles. Although this notion has a primary meaning, which refers to the intrinsic value of human beings, it has multiple functions, which operate at different levels. First of all, 
dignity provides the deepest justification for human rights. But it is also often mentioned, for instance, as the ultimate reason behind the prohibition of discriminatory practices, as well as an argument against torture, inhuman and degrading treatment and punishment, and various forms of instrumentalization of people (slavery, organ trafficking, etc.). In this regard, the UNESCO Universal Declaration on Bioethics and Human Rights is a good example of the various roles that human dignity can play. As noted above, the promotion of respect for human dignity constitutes not only the main purpose of the document (Article 2.c) but also the first principle that should govern biomedical issues (Article 3), the rationale for the prohibition of discrimination and stigmatization of individuals or groups of individuals (Article 11), the framework within which cultural diversity is to be respected (Article 12), and the interpretative principle for a correct understanding of all the Declaration's provisions (Article 28).

\section{THE NECESSARY RECOURSE TO HUMAN RIGHTS}

The key role attached to human dignity in global bioethics is necessary but not sufficient for providing an effective response to the complex challenges posed by biomedical clinical and research practice. Dignity alone cannot directly solve most bioethical dilemmas because it is not a magic word that provides immediate response to them. Some further explanations are usually required to indicate why some practices are considered to be in conformity (or not) with what is required by the intrinsic worth of human beings. Thus, to become functional, dignity needs other more concrete notions that are normally formulated using the terminology of "rights" (e.g., informed consent, physical integrity, confidentiality, nondiscrimination, etc.). Human dignity and human rights are therefore mutually dependent but in different ways. The relationship between them is that of a principle and the concrete legal norms that are needed to flesh out that principle in real life. In other words, although we need to recur to human dignity as the ultimate justification of legal norms, "the practical business of pressing one's interests against others" is conducted in terms of claimed human rights (Beyleveld and Brownsword, 2002, 13).

The need to appeal to human rights for governing biomedicine is even greater at the global level. As our world becomes increasingly interconnected and threats to global public health continue to proliferate, it is hard to see how the global governance of health could be managed without assigning an integral role to human rights (Gable, 2007, 534). It is therefore not by chance that the 2005 UNESCO Declaration constantly adds a reference to "human rights" every time that it mentions human dignity. In fact, as it was said above, the whole declaration is conceived as an extension of international human rights law into the field of biomedicine. The importance of this document lies precisely in the fact that it is the first intergovernmental global 
instrument that addresses, from a broad perspective, the linkage between human rights and bioethics (Andorno, 2007, 150). In this regard, the chairperson of the drafting group of the Declaration does not hesitate to affirm that "the most important achievement of the text" consists precisely in having integrated the bioethical analysis into a human rights framework (Kirby, 2006, 126). As noted by the Explanatory Memorandum to the Preliminary Draft Declaration, "the drafting group also stressed the importance of taking international human rights legislation as the essential framework and starting point for the development of bioethical principles" (UNESCO, 2005, Para. 11). This document also points out that there are two broad streams at the origin of the norms dealing with bioethics. The first one can be traced to antiquity, in particular to Hippocrates, and is derived from reflections on the practice of medicine. The second one, conceptualized in more recent times, has drawn upon the developing international human rights law. Furthermore, it states: "One of the important achievements of the declaration is that it seeks to unite these two streams. It clearly aims to establish the conformity of bioethics with international human rights law" (UNESCO, 2005, Para. 12).

Several reasons explain the appeal to human rights to establish global norms in bioethics. As mentioned above, there is a very close relationship between biomedical activities and the most basic human rights such as the right to life and to physical integrity. Therefore, it is not surprising that both modern bioethics and international human rights were born from the same historical events: the Second World War, the Holocaust, and the Nuremberg tribunals that condemned the Nazi doctors (Annas, 2005, 160). The common origin of both systems makes even more understandable the recourse to the existing human rights framework to protect individuals from harm in the biomedical field.

Moreover, the human rights approach facilitates the formulation of universal standards because international human rights law is grounded on the assumption that basic rights transcend cultural diversity. Human rights are indeed conceived as entitlements that people have simply by virtue of their human condition and regardless of their ethnic origin, sex, age, socioeconomic status, health condition, or religious or political ideas. Human rights are held to be universal in the sense that "all people have and should enjoy them, and to be independent in the sense that they exist and are available as standards of justification and criticism whether or not they are recognized and implemented by the legal system or officials of a country" (Nickel, 1987, 561). In such a sensitive field as bioethics, where diverse sociocultural, philosophical, and religious traditions come into play, the importance of having principles of universal validity should not be underemphasized.

A more practical reason for the use of a human rights framework in this field is that there are few, if any, mechanisms available other than human rights to function as a "global normative foundation" in biomedicine (Thomasma, 2001, 300) or as a "lingua franca of international relations" (Knowles, 2001, 253). 
As a well-known expert on public health issues has pointed out, "the human rights framework provides a more useful approach for analyzing and responding to modern public health challenges than any framework thus far available within the biomedical tradition" (Mann, 1996, 924). Similarly, it has been argued that the recourse to human rights is fully justified on the ground that bioethics suffers from the plurality and range of actors involved and the overproduction of divergent norms, whereas human rights offers "a strong framework and a common language, which may constitute a starting point for the development of universal bioethical principles" (Boussard, 2007, 114).

\section{SOME OBJECTIONS TO THE USE OF A HUMAN RIGHTS APPROACH}

The use of a human rights framework to set up global norms on bioethics must often face the objection that human rights are a Western ideological construct of little relevance in non-Western (mainly African and Asian) societies. A corollary of this view is the argument that attempts to impose human rights values on non-Western countries amount to cultural imperialism (Schroeder, 2005, 221-3). This objection is often linked to a moral relativistic position according to which moral principles are thought of as socially and historically contingent, valid only for those cultures and societies in which they originate. Consequently, there is no such thing as universally valid moral principles, not even the idea that people have inherent dignity and rights.

Although the philosophical debate between universalists and relativists is far too complex to be adequately covered in this paper, some responses to the first of the above-mentioned criticisms are immediately available. First, it is true that the notion of human rights has recent origins in the European Enlightenment philosophers and in the political revolutions of the end of the eighteenth century, notably, the American and French Revolutions. However, this historical circumstance does not necessarily invalidate the widely accepted claim that people should be entitled to basic rights by the mere fact of being humans. This is the relevant question, no matter where the idea of such inherent rights comes from (Andorno, 2007, 152). Merely pointing to moral diversity and the presumed integrity of individual cultures does not, by itself, provide a philosophical justification for relativism or a sufficient critique of universalism.

As a matter of fact, international human rights law has been elaborated by representatives of the most diverse countries and cultures and is not intended to impose one cultural standard, but rather to promote a legal standard of minimum protection necessary for human dignity. As such, universal human rights can be reasonably seen as the "hard-won consensus of the international community" and not as the cultural imperialism of any particular 
region or set of traditions (Ayton-Shenker, 1995, 2). Even though the modern conceptualization of human rights is an historical product of Western civilization, the idea, which is at the heart of this notion (that every human being deserves to be respected), is present though in different conceptual terms, in every human society.

In addition to the criticism of "cultural imperialism," it is also argued that human rights are conceived as excessively individualist for non-Western mentalities and lack a significant concern for personal duties and for the common interest of society. It is true that human rights have been originally conceived having in mind the individual person as the principal bearer of such rights. However, it would be equally fair to say that international law has made substantial efforts over the last decades to be more attuned to the communal and collective basis of many non-Western societies. This was done, in particular, through the development of the "second generation of rights" that are included in the above-mentioned ICCPR 1966, such as the right to education, the right to social security, the right to a fair remuneration, the right to healthy working conditions, the right to health care, the protection of the family and children, the right to adequate housing, etc. This trend toward a broader understanding of human rights has been even further developed with the "third generation of human rights," the so-called "rights of solidarity" or "rights of groups," which include the right to development, to peace, to self-determination, and to a healthy environment. In sum, although human rights remain philosophically grounded within an individualist moral doctrine, there can be no doubt that serious attempts are being made by the international community to adequately apply them to more communally oriented societies.

In any case, the truth is that today these theoretical controversies have lost much of their practical significance. The first reason for this is that, at present, virtually all states accept the authority of international human rights law. The six core international human rights treaties (on civil and political rights, economic, social, and cultural rights, racial discrimination, women, torture, and children) have an average 166 ratifying states, which represents a truly impressive $85 \%$ ratification rate (Volodin, 2007, 15-23). The second reason is that human rights emerge from international law instruments with sufficient flexibility to be compatible with respect for cultural diversity. The universality of human rights norms is not incompatible with some local variations in the form in which particular rights are implemented (Donnelly, 1989, 109-42).

\section{CONCLUSION}

One of the most impressive features of the emerging international instruments relating to bioethics is that they assign a very central role to the principle of respect for human dignity. The UNESCO Universal Declaration on 
Bioethics and Human Rights is a good example of this trend. Although the Declaration does not provide a definition of human dignity, this notion is usually understood as referring, first, to the intrinsic worth of human beings and second, in a derivative way, to the value of humanity as such. But the emerging international biolaw also appeals to human rights to set up global norms in this field. Several reasons justify this strategy: the obvious link between health issues and basic human rights; the universalistic claim of human rights, which facilitates the formulation of transcultural standards; the fact that the key notions employed at the domestic level to protect people from misuse in the biomedical field are already formulated using the terminology of rights; and the lack of any conceptual and institutional instrument other than human rights to produce an international framework of norms relating to biomedicine.

\section{REFERENCES}

Andorno, R. 2007. Global bioethics at UNESCO: In defence of the universal declaration on bioethics and human rights. Journal of Medical Ethics 33:150-4.

Annas, G. J. 2005. American bioethics: Crossing human rights and health law boundaries. New York: Oxford University Press.

Annas, G. J., L. Andrews, and R. Isasi. 2002. Protecting the endangered human: Toward an international treaty prohibiting cloning and inheritable alterations. American Journal of Law and Medicine 28:151-78.

Ayton-Shenker, D. 1995. The challenge of human rights and cultural diversity: United Nations background note. New York: United Nations Department of Public Information [Online]. Available: http://www.un.org/rights/dpi1627e.htm (Accessed November 5, 2008).

Beyleveld, D., and R. Brownsword. 2002. Human dignity in bioethics and biolaw. Oxford: Oxford University Press.

Birnbacher, D. 1996. Ambiguities in the concept of Menschenwürde. In Sanctity of life and buman dignity (pp. 107-21), ed. K. Bayertz. Dordrecht, The Netherlands: Kluwer.

Boussard, H. 2007. The 'normative spectrum' of an ethically-inspired legal instrument: The 2005 universal declaration on bioethics and human rights. In Biotechnologies and international buman rights (pp. 97-127), ed. F. Francioni. Oxford: Hart Publishing.

Callahan, D. 2004. Bioethics. In Encyclopedia of bioethics (pp. 278-87), ed. S. Post. 3rd ed. New York: Macmillan.

Cançado Trinidade, A. 2008. Universal declaration of human rights. United Nations Audiovisual Library of International Law (pp. 1-4) [On-line]. Available: http://untreaty.un.org/ cod/avl/ha/udhr/udhr.html. (Accessed November 5, 2008).

Caulfield, T., and A. Chapman. 2005. Human dignity as a criterion for science policy. PLOS Medicine 2:736-8.

Cohen, C. B. 2002. Public policy and the sale of human organs. Kennedy Institute of Ethics Journal 12:47-64.

Dimitrijevic, V. 2006. Customary law as an instrument for the protection of human rights. ISPI (Istituto per gli Studi di Politica Internazionale) Working Papers 7:1-28 [On-line]. Available: http://www.ispionline.it/it/documents/wp_7_2006.pdf (Accessed November 5, 2008). 
Donnelly, J. 1989. Universal human rights in theory and practice. Ithaca, NY: Cornell University Press.

Dworkin, R. 1994. Life's dominion: An argument about abortion, euthanasia and individual freedom. New York: Vintage.

Faunce, T. 2005. Will international human rights subsume medical ethics? Intersections in the UNESCO Universal Bioethics Declaration. Journal of Medical Ethics 31:173-8.

Gable, L. 2007. The proliferation of human rights in global health governance. Journal of Law, Medicine E Ethics 35:534-44.

Gewirth, A. 1982. Human rights: Essays on justification and applications. Chicago: University of Chicago Press.

Hillgenberg, H. 1999. A fresh look at soft law. European Journal of International Law 10:499-515.

Iglesias, T. 2001. The dignity of the individual: Issues of bioethics and law. Dublin, Republic of Ireland: Pleroma.

Jellinek, G. 1908. Die sozialethische Bedeutung von Recht, Unrecht und Strafe. Berlin, Germany: Häring.

Kant, I. 1996. Groundwork of the metaphysics of morals. In Practical philosophy (pp. 37-108), ed. M. Gregor. The Cambridge edition of the works of Immanuel Kant. Cambridge: Cambridge University Press.

Kirby, M. 2006. UNESCO and universal principles on bioethics: What's next? In Twelfth session of the International Bioethics Committee (IBC) December 2005 Proceedings (pp. 121-36), ed. UNESCO, Division of Ethics of Science and Technology. Paris, France: UNESCO [On-line]. Available: http://unesdoc.unesco.org/images/0014/001484/148404e.pdf. (Accessed November 5, 2008).

Knowles, L. 2001. The lingua franca of human rights and the rise of a global bioethic. Cambridge Quarterly of Healthcare Ethics 10:253-63.

Lenoir, N., and B. Mathieu. 1998. Les normes internationales de la bioéthique. Paris, France: Presses Universitaires de France.

Macklin, R. 2003. Dignity is a useless concept. British Medical Journal 327:1419-20.

Manaï, D. 2006. Les droits du patient face à la biomedicine. Berne, Switzerland: Stämpfli.

Mann, J. 1996. Health and human rights. Protecting human rights is essential for promoting health. British Medical Journal 312:924-5.

Nickel, J. 1987. Making sense of human rights: Philosophical reflections on the universal declaration of human rights. Berkeley: University of California Press.

Schachter, O. 1983. Human dignity as a normative concept. The American Journal of International Law 77:848-54.

Schroeder, D. 2005. Human rights and their role in global bioethics. Cambridge Quarterly of Healthcare Ethics 14:221-3.

Spaemann, R. 1996. Personen. Versuche über den Unterschied zwischen, etwas 'und,jemand'. Stuttgart, Germany: Klett-Cotta.

Spiegelberg, H. 1970. Human dignity: A challenge to contemporary philosophy. In Human dignity. This century and the next (pp. 39-62), eds R. Gotesky, and E. Laszlo. New York: Gordon and Breach.

Szasz, P. 1992. International norm-making. In Environmental change and international law: New challenges and dimensions (pp. 41-70), ed. E. Brown Weiss. Tokyo, Japan: United Nations University Press. 
Thomasma, D. 2001. Proposing a new agenda: Bioethics and international human rights. Cambridge Quarterly of Healthcare Ethics 10:299-310.

UNESCO. 2004. Towards a declaration on universal norms on bioethics. Report of the Extraordinary Session of the International Bioethics Committee, rapporteur L. de Castro. Paris, France: UNESCO [On-line]. Available: http://portal.unesco.org/shs/en/files/5997/109205 51251rappExtraCIB_en.pdf/rappExtraCIB_en.pdf (Accessed November 5, 2008).

- 2005. Explanatory memorandum on the elaboration of the preliminary draft declaration on universal norms on bioethics. Paris, France: UNESCO [On-line]. Available: http:// unesdoc.unesco.org/images/0013/001390/139024e.pdf (Accessed November 5, 2008).

Volodin, V., ed. 2007. Human rights. Major international instruments. Status as at 31 May 2007. Paris, France: UNESCO [On-line]. Available: http://unesdoc.unesco.org/ images/0015/001528/152899m.pdf (Accessed November 5, 2008). 